Ind. Health, 1970, 8, 17.

\title{
STUDIES ON LYSOZYME II
}

\section{PREPARATION OF RADIOACTIVE EGG WHITE LYSOZYME IN VIVO}

\author{
Masami KIMURA, Noriko OTAKI, \\ Ikuko NAKAE* and Shizuko KOBAYASHI* \\ National Institute of Industrial Health, Kizuki-Sumiyoshi, Kawasaki
}

(Received April 6, 1970)

\begin{abstract}
A white leghorn hen was injected with tryptophan-3-C $\mathrm{C}^{14}$. The labelled lysozyme was prepared by the DEAE-cellulose chromatography from the radioactive egg white obtained during 24-48 hours after the injection.

It was elucidated that the tryptophan-3- $\mathrm{C}^{14}$ was incorporated into only tryptophan residues of lysozyme molecule.
\end{abstract}

\section{INTRODUCTION}

It has been expected to obtain the radioactive lysozyme for an investigation of the behaviour of lysozyme in living cells. In 1962, Mandeles and Ducay (1) isolated chromatographically the radioactive conalbumin, ovalbumin and lysozyme from egg white after injection of lysine-1- $\mathrm{C}^{14}$ and glutamic acid-1-C ${ }^{14}$ into a laying hen. We have also prepared the radioactive lysozyme labelled with tryptophan-3 $\mathrm{C}^{14}$ in vivo.

\section{ExPERIMENTAL Methods}

A white leghorn hen was injected intravenously with $1.0 \mathrm{ml}$ of DL-tryptophan$3-\mathrm{C}^{14}$ aqueous solution $(0.1 \mathrm{mc}$; specific radioactivity: $52 \mathrm{mCi} / \mathrm{mmole}$; Daiichi Pure Chemicals, Tokyo. Lot No. 210-10). The eggs were collected subsequently, the whites separated from the yolks. The radioactivities and lysozyme contents of the lyophilized egg whites obtained during first 16 days after injection of tryptophan-3-C ${ }^{14}$ were determined.

The white was dissolved in $30 \mathrm{ml}$ of $0.02 \mathrm{M}$ glycine and followed by centrifugation $(10,000 \mathrm{rpm}, 10 \mathrm{~min})$ for removal of insoluble materials. The supernatant was charged on a column $(5 \times 50 \mathrm{~cm})$ of DEAE-cellulose, equilibrated with 0.02 $\mathrm{M}$ glycine. The elution was stepwise carried out by $0.02 \mathrm{M}$ glycine and a mixture of $0.02 \mathrm{M}$ glycine, $0.1 \mathrm{M} \mathrm{KH}_{2} \mathrm{PO}_{4}, 0.1 \mathrm{M} \mathrm{NaCl}$ and $0.03 \mathrm{~N} \mathrm{HCI}$ by the method of Mandeles (2). The radioactive lysozyme fractions were pooled, and followed by

* Present address: The Kyoritsu College of Pharmacology, Tokyo. 


\section{KIMURA, N. OTAKI, I. NAKAE AND S. KOBAYASHI}

dialysis in a Visking tube (32/36 inches) against distilled water. The salt-free lysozyme was again dissolved in $10 \mathrm{ml}$ of $0.02 \mathrm{M}$ glycine after lyophilization, and then it was rechromatographed on a column $(5 \times 40 \mathrm{~cm})$ of DEAE-cellulose by the elution method as described above. The radioactive lysozyme fractions were pooled, dialysed against distilled water, and then lyophilized. Some preparations were subjected to gel filtration on a column $(5 \times 100 \mathrm{~cm})$ of Bio Gel P-2 (50-100 mesh) with $1 \%$ acetic acid after DEAE-cellulose chromatography.

Lysozyme content was assayed by lytic activity against Micrococcus lysodeikticus (3). The fresh suspension $(3.0 \mathrm{ml})$ which contained $0.3 \mathrm{mg}$ of lyophilized cells per $\mathrm{ml}$ in $1 / 15 \mathrm{M}$ phosphate buffer, $\mathrm{pH} 6.2$, was incubated with $1.0 \mathrm{ml}$ of $0.3 \mathrm{M}$ $\mathrm{NaCI}-1 / 15 \mathrm{M}$ phosphate buffer, $\mathrm{pH} 6.2$, for 3 minutes at $35^{\circ} \mathrm{C}$. The sample $(0.1$ $\mathrm{ml}$ ) was added to $4.0 \mathrm{ml}$ of the cell suspension, and followed by incubation for 5 minutes at $35^{\circ} \mathrm{C}$. A decrease of turbility of the mixture at $540 \mathrm{~m}_{\mu}$ was mesured. Lysozyme content was estimated by reference to the standard hen egg white lysozyme (6X recrystallized, Seikagaku Kogyo Co., Tokyo). Radioactivity was determined for the sample $(0.05 \mathrm{ml})$ in $10 \mathrm{ml}$ of a scintillator (toluene-methanol, 7/ 3 by volume, $0.4 \%$ PPO and $0.02 \%$ POPOP) by a liquid scintillation spectrometer, Packard Model 3003. The purified lysozyme was dissolved in water, and followed similarly by the determination of lytic activity and radioactivity.

\section{RESUls AND Discussion}

The analytical results of radioactivities and lysozyme contents of egg whites are shown in Fig. 1. The weight of lyophilized egg white was approximately $4 \mathrm{~g}$ and the lysozyme content was about $40 \mathrm{mg}$ per $\mathrm{g}$ of lyophilized egg white. It can be seen that the radioactivity is chiefly found in the egg white during 24 to 48 hours after injection of tryptophan-3-C ${ }^{14}$. The white (e.g. $4.2 \mathrm{~g}: 4.85 \times 10^{6} \mathrm{cpm}$; $151.1 \mathrm{mg}$ of lysozyme; from the egg of hen $\mathrm{D}$ on the second day as shown in Fig. 1) was treated. Fig. 2 shows the elution diagrams of radioactive lysozyme on DEAE-cellulose column chromatography. $30.5 \mathrm{mg}$ (total counts : $0.34 \times 10^{6} \mathrm{cpm}$ ) of radioactive hen egg white lysozyme was obtained from this white. The mean recovery of lysozyme and radioactivity in some preparations were $20-40 \%$ and 5 $10 \%$ for the original egg white, respectively.

The lytic activity of radioactive lysozyme was nearly equal to that of the standard one. It moved as a single zone of protein when subjected to Disc electrophoresis at $\mathrm{pH} 4.0$ and 8.6 (4). The amino acid composition of radioactive lysozyme was identical with that of the standard one. Six tryptophan residues were found to react with 2-hydroxy-5-nitrobenzyl bromide $(5,6)$ after denaturation with $5 \mathrm{M}$ guanidine hydrochloride.

With the object of confirming that only tryptophan residues of lysozyme molecule were labelled, the radioactive lysozyme was enzymatically digested with papain which was prepared by the method of Kimmel and Smith ( 7 ) and leucine amino peptidase (Worthington Biochemicals Co., LAPDEP 61c) according to the 
STUDIES ON LYSOZYME II

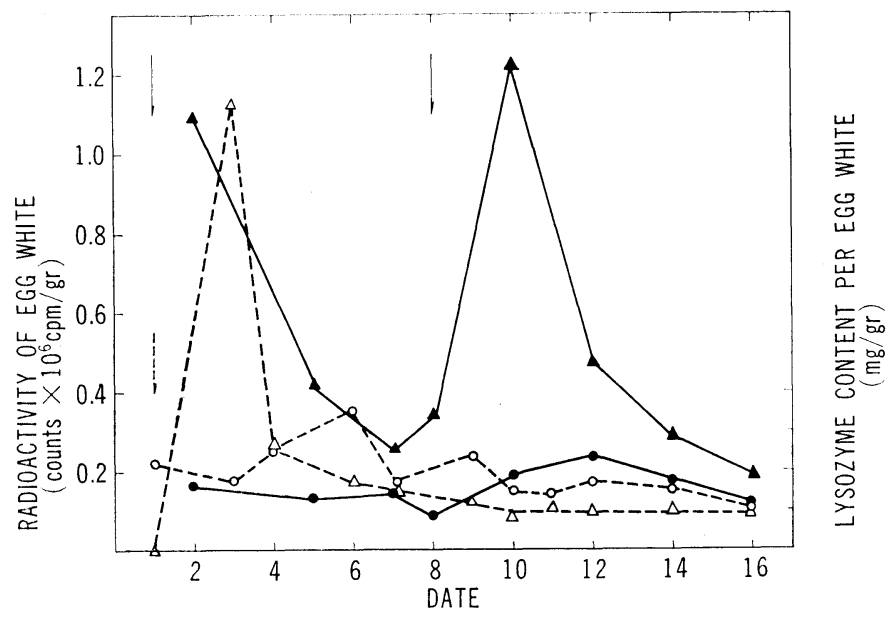

Fig. 1 Radioactivity and lysozyme content of egg white obtained after injection of tryptophan-3-C ${ }^{14}$. Tryptophan-3-C ${ }^{14}$ aqueous solution (total counts; $\left.1.31 \times 10^{8} \mathrm{cpm}\right)$ was injected into hen $\mathrm{A}(\longrightarrow)$ two times and into hen $\mathrm{D}(\cdots \cdots \rightarrow)$ one time, respectively. Symbols of -- and $\cdots \bigcirc \cdots$ present lysozyme content of hen A and D egg white. Symbols of $-\mathbf{A}-$ and $\cdots \triangle \cdots$ present radioactivity of hen $\mathrm{A}$ and $\mathrm{D}$ egg white.

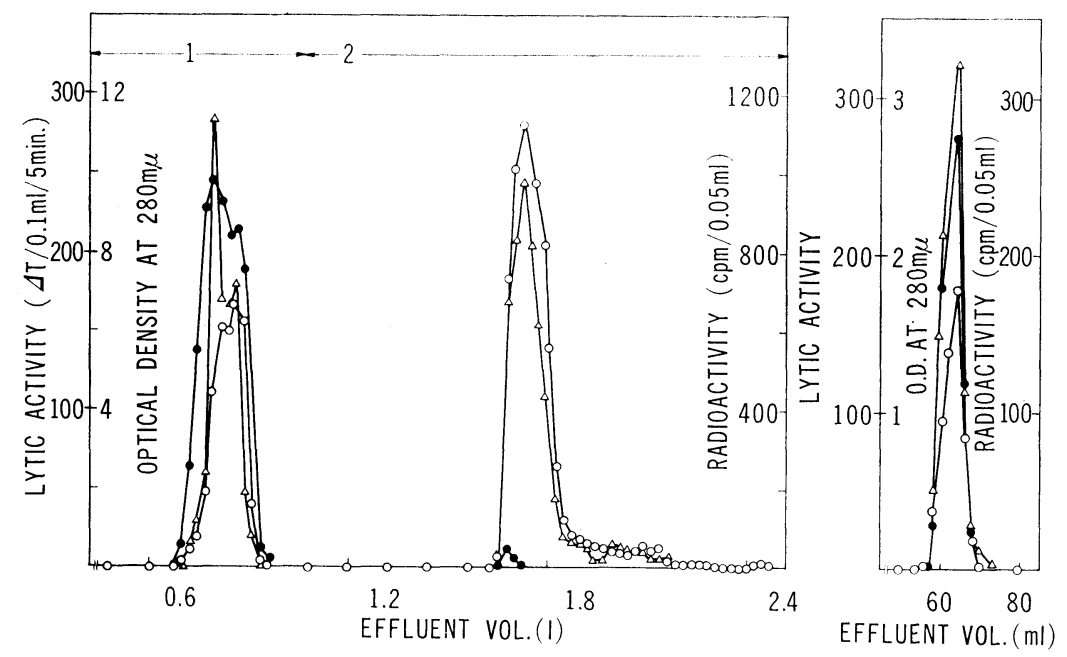

Fig. 2. Chromatography of radioactive lysozyme on DEAE-cellulose. The first chromatography is left, and the second one is right. Symbols of - - $-O$ and $-\triangle-$ present optical density at $280 \mathrm{~m}_{\mu}$, lytic activity and radioactivity.

method of Hill and Schmidt (8). The digest was analysed by a amino acid analyser (Hitachi Model 034) which effluent run through a flow cell $(2.0 \mathrm{ml}$ ) with anthracene as a scintillator in a liquid scintillation spectrometer before it mixed with ninhydrin solution. The elution pattern of basic amino acids and the result of amino acid analysis are shown in Fig. 3. The radioactive peak, in the order of elution, represents tryptophan. It may be evidence for the incorporation of 
M. KIMURA, N. OTAKI, I. NAKAE AND S. KOBAYASHI

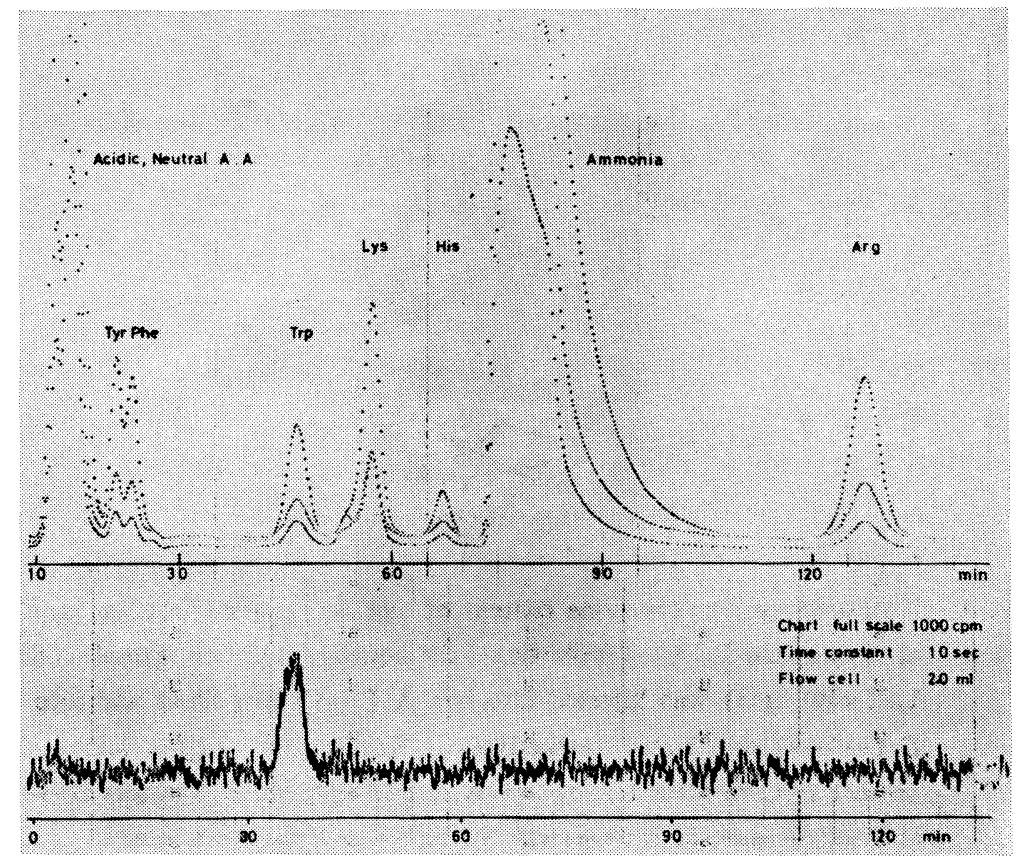

Fig. 3. Analysis of radioactive tryptophan in lysozyme. A column of Aminex A5 $(0.9 \times 15 \mathrm{~cm})$ maintained at $55^{\circ} \mathrm{C}$ was used for analysis of enzymic digest of radioactive lysozyme $(0.66 \mathrm{mg})$ with papain and leucine amino peptidase. Flow rate was $60 \mathrm{ml}$ per hour. The yield was $64 \%$ for origianal lysozyme. Amino acid composition of radioactive lysozyme observed from acid hydrolysates $(6 \mathrm{~N} \mathrm{HCI})$ at $110^{\circ} \mathrm{C}$ for 24 hours; Lys : 6.0, His : 0.6, Arg: 10.2, Asp : 20.7, Thr: 6.3 (not corr.), Ser : 10.0 (not corr.), Glu: 4.9, Pro: 1.9, Gly : 12.1, Ala: 12.0 (as standard), Half-Cys : 2.1, Val : 5.6, Met: 1.9, Ileu: 5.8, Leu: 8.1, Tyr: 2.8, Phe : 2.9, Trp : 6.1 (from this figure).

tryptophan-3-C $\mathrm{C}^{14}$ into only tryptophan residues of lysozyme molecule.

It is posible to use the radioactive lysozyme for the determination of distribution and absorption of lysozyme in vivo. Also, the radioactive lysozym is probably effective as a standard protein for the C-terminal' analysis with tritium labelling method (9).

\section{REFERENCES}

1) Mandeles, S. and Ducay, E. D. (1962). J. Biol. Chem., 237, 3196.

2) Mandeles, S. (1960). J. Chromatog. 3, 256.

3) Parry, R. M., Chandan, R. C. and Shahani, K. M. (1965). Proc. Soc. Exptl. Biol. Med., 119, 384.

4) Reisfeld, R. A., Lewis, U. J. and Williams, D. E. (1962). Nature, 195, 281.

5) Koshland, Jr., D. E., Karkhanis, Y. D. and Latham, H. G., (1964) J. Am. Chem. Soc., 86, 1448. 


\section{STUDIES ON LYSOZYMES II}

6) Bewley, T. A. and Li, C. H. (1965). Nature, 206, 624.

7) Kimmel, J. R. and Smith, E. L. (1954). J. Biol. Chem., 207, 515.

8) Hill, R. L. and Schmidt, W. R. (1962). J. Biol. Chem., 237, 389.

9) Matsuo, H. (1969). Proteins, Nucleic Acids and Enzymes, (Tokyo) 14, 523; 589. 